Scholarship Repository

University of Minnesota Law School

Articles

Faculty Scholarship

1988

\title{
The 39th Session of the UN Sub-Commission on Prevention of Discrimination and Protection of Minorities
}

\author{
Sonia Rosen \\ David Weissbrodt \\ University of Minnesota Law School, weiss001@umn.edu
}

Follow this and additional works at: https://scholarship.law.umn.edu/faculty_articles

Part of the Law Commons

\section{Recommended Citation}

Sonia Rosen and David Weissbrodt, The 39th Session of the UN Sub-Commission on Prevention of Discrimination and Protection of Minorities, 10 HUM. RTS. Q. 487 (1988), available at https://scholarship.law.umn.edu/faculty_articles/408.

This Article is brought to you for free and open access by the University of Minnesota Law School. It has been accepted for inclusion in the Faculty Scholarship collection by an authorized administrator of the Scholarship Repository. For more information, please contact lenzx009@umn.edu. 


\section{The 39th Session of the UN Sub-Commission on Prevention of Discrimination and Protection of Minorities}

\section{Sonia Rosen and David Weissbrodt}

The 39th session of the UN Sub-Commission on Prevention of Discrimination and Protection of Minorities (Sub-Commission) was held from 10 August through 4 September 1987 in Geneva, Switzerland. The Sub-Commission, established in 1947 as a subsidiary body of the Commission on Human Rights (Commission), is composed of 26 experts who are elected by the Commission. The experts are elected in their individual capacities rather than as representatives of their governments. The Sub-Commission meets annually in August-September to undertake studies and make recommendations to the Commission on a wide range of human rights topics. ${ }^{7}$

1. The official report of the 39th session of the Sub-Commission may be found in U.N. Doc. E/CN.4/1988/37 and U.N. Doc. E/CN.4/Sub.2/1987/42 [hereinafter cited as 1987 Report]. For analyses of past sessions of the Sub-Commission see generally Tolley, H. Jr., The U.N. Commission on Human Rights, (1987); Haver, The United Nations Sub-Commission on the Prevention of DIscrimination and the Protection of Minorities, 21 Colum. J. Transnat' 1 L. 103 (1982); Garber and O'Connor, The 1984 U.N. Sub-Commission on Prevention of Discrimination and Protection of Minorities, 79 AJIL 168 (1985); Hantke, The 1982 Session of the U.N. Sub-Commission on Prevention of Discrimination and Protection of Minorities: Current Developments, 77 AJIL 651 (1983); Gardeniers, Hannum and Kruger, The U.N. Sub-Commission on Prevention of Discrimination and Protection of Minorities: Recent Developments, 4 Hum. Rts. Q. 353 (1982); Gardeniers, Hannum and Kruger, The 1981 Session of the U.N. Sub-Commission on Prevention of Discrimination and the Protection of Minorities: Current Developments, 76 AJIL 405 (1982); Hannum, Human Rights and the United Nations: Progress at the 1980 Session of the U.N. Sub-Commission on Prevention of Discrimination and Protection of Minorities, 3 Hum. Rts. Q. 1 (1981); Hannum, The Thirty-Third Session of the U.N. Sub-Commission on Prevention of Discrimination and Protection of Minorities, 75 AJIL 172 (1981); Humphrey, The United Nations Sub-Commission on the Prevention of Discrimination and the Protection of Minorities, 62 AJIL 869 (1968). Further information concerning the Sub-Commission and human rights in the United Nations may be found in the Human Rights Internet Reporter, the ICJ Review (published by the International Commission of Jurists), the AIUSA Legal Support Network Newsletter, and the newly established Analytical Reports of the International Service for Human Rights. 
Due to the recent financial crisis of the United Nations, caused mainly by the failure of the United States to pay most of its assessed contribution to the United Nations, the 1986 session of the Sub-Commission was cancelled. The terms of the members of the Sub-Commission, due to expire after the 1986 session, were extended for one year so that they might serve the last year of their term on the Sub-Commission in $1987 .{ }^{2}$ The next elections for the Sub-Commission were later held at the February-March 1988 session of the Commission. ${ }^{3}$

Because the 1986 session was cancelled, the members of the 39 th session were forced to consider an enlarged agenda containing issues held over from 1985. The outgoing Chair of the Sub-Commission, Mrs. Erica-Irene Daes from Greece, spoke at the beginning of the 1987 session and expressed the opinion of all the experts in declaring that the work of the Sub-Commission in the area of human rights is much too vital to allow any more cancellations of its meetings.

This article discusses the organization of the 39th session of the SubCommission and summarizes the highlights of the session. The article then considers in slightly greater detail a few of the more important issues discussed and the resolutions adopted. These issues relate to gross violations of human rights in various countries of the world, the rights of indigenous peoples, problems concerning detention, and other issues raised by the work of the Sub-Commission.

\section{ORGANIZATION OF THE SESSION}

The Sub-Commission began its work by electing Mr. Leandro Despouy (Argentina) as Chair. ${ }^{4}$ The Sub-Commission elected three Vice Chairs: Messrs.

2. E.S.C. Dec. $1987 / 102$.

3. In 1988, the Commission for the first time elected new members of the Sub-Commission for staggered two and four year terms. See 1988 Report of the Commission on Human Rights, U.N. Doc. E/CN.4/1988/88, at 274-76 [hereinafter cited as 1988 Comm'n Report].

4. The chairmanship of the Sub-Commission traditionally rotates among the five regions represented (Africa [19831, Asia [1982], Eastern Europe [1984], Latin American and the Caribbean [1987], and Western Europe and others [1985]). This year, the responsibility for nominating a chair fell to the three members from Latin American and the Caribbean: Mr. Despouy (Argentina), Mr. Alfonso Martinez (Cuba), and Senator Martinez-Baez (Mexico). During the 1985 session of the Sub-Commission, the Western European countries could not reach a consensus on which person was to be nominated for the position of chair (Mrs. Daes from Greece was eventually nominated and served as chair). During the week prior to the 39th session of the Sub-Commission, Mr. Alfonso Martinez actively expressed his desire to be chair. This, obviously, was not the unanimous will of the other regional members, as Mr. Despouy who was the alternate expert from Argentina eventually was elected by consensus. Mr. Alfonso Martinez was given a consolation prize of being named a Special Rapporteur in exchange for agreeing to give up his campaign to be a chair of the Sub-Commission. 
Murlidhar Chandrakant Bhandare (India), Kwesi B. S. Simpson (Ghana), and Danilo Turk (Yugoslavia). Mr. Louis Joinet of France was elected as Rapporteur. ${ }^{5}$ Of the twenty-six experts elected to the Sub-Commission, eighteen were present, four were represented by their alternates, and four were absent. By electing two alternate experts as officers of the 39th session (Despouy and Turk), the Sub-Commission took an informal but distinct position in recognizing the role of alternates as equal to that of elected experts. ${ }^{6}$

The opening of the session was marred by the sudden death of Mr. Justice Abu Sayed Chowdhury who, having served as the expert from Bangladesh since 1978, passed away en route to the Sub-Commission. A minute of silence was observed in his memory. The Sub-Commission also took note of the absence of Mr. Mazilu, the expert from Romania. Mrs. Daes expressed concern that Mr. Mazilu, reportedly unable to attend the Sub-Commission due to illness, was apparently prevented from attending the session by his

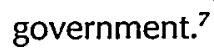

\section{HIGHLIGHTS OF THE 1987 SESSION}

The 39th session of the Sub-Commission produced a number of positive as well as a few disappointing results. Some of the more positive highlights included: (1) the progress of the Working Group on Indigenous Populations in preparing a set of draft principles for a future declaration on indigenous rights; $^{8}(2)$ a decision ${ }^{9}$ expressing the concern that a draft body of principles

5. The officers of the Sub-Commission, known collectively as the Bureau, change from year to year. Each geographical region holds one of the five positions. The Chair has general powers to preside over the session, including setting the list and time limit of speakers, ruling on points of order and putting questions to a vote. Rules of Procedure of the Functional Commissions of the Economic and Social Council, rule 41, U.N. Doc. E/5975/Rev. 1. It is customary practice for the Chair to refrain from voting on resolutions of the SubCommission. The three Vice-Chairs act as Chair in the event the Chair is absent from the meeting. The Rapporteur serves as the secretary of the session and is responsible for preparing the final report of the Sub-Commission.

6. Until the adoption of Commission on Human Rights resolution 1983/21 Thereinafter resolutions of the Commission cited as Comm'n Res.], there existed no established standards for the selection of alternates. The Commission became increasingly concerned that Governments were appointing governmental representatives as alternates to serve in place of independent experts, thereby eroding the independent and less political make-up of the Sub-Commission. In 1983, the Commission authorized the election of one alternate for each delegation, stating that the same criteria for nominating an independent expert would apply to the nomination of alternates. Comm'n Res. 1983/21. Since then, numerous alternates have represented their countries at the Sub-Commission.

7. The unexplained absence of Mr. Mazilu from the session was noted with concern by the Irish representative to the Commission, expressing the importance of experts not only being independent, but allowed to fulfill their mandates. See United Nations Press Release, HRJ 2149, 26 Feb. 1988.

8. Sub-Comm'n Res. 1987/15, 1987 Report at 26-27. See also Report of the Working Group on Indigenous Populations, U.N. Doc. E/CN.4/Sub.2/1987/22 and Add.1.

9. Sub-Comm'n Dec. 1987/108, 1987 Report at 52-53. 
for the protection of detainees has been weakened by the Sixth Committee of the General Assembly ${ }^{10}$ to the point of falling short of protections provided in existing international norms; and (3) a recommendation by the Working Group on Detention to examine current work in the field of developing international standards for adequate investigations into all cases of suspicious deaths in detention, as well as adequate autopsy standards. ${ }^{11}$

The Sub-Commission also recommended the establishment of a new Special Rapporteur on economic, social and cultural rights, ${ }^{12}$ as well as a Special Rapporteur on treaties involving indigenous peoples. ${ }^{13}$ The SubCommission requested that a study on administrative detention ${ }^{14}$ be considered at its 40 th session in 1988. A study by the Secretary-General on the relationship between human rights and international peace and security will be discussed at the 40th session. ${ }^{15}$ Two issues were added to the agenda of the Sub-Commission: human rights in Cyprus ${ }^{16}$ and the status of women in the new international economic order. ${ }^{17}$

One problem with the 39th session of the Sub-Commission was the lack of substantive consideration of the many important scholarly studies undertaken, for example, the studies on a second optional protocol to the International Covenant on Civil and Political Rights aiming at the abolition of the death penalty ${ }_{i}{ }^{18}$ on the independence and impartiality of the judiciary, jurors and assessors, and the independence of lawyers; ${ }^{19}$ on religious intolerance; ${ }^{20}$ and on the right to leave and return. ${ }^{21}$ Although publicly intro-

10. Draft Body of Principles for the Protection of All Persons Under Any Form of Detention or Imprisonment, U.N. Doc. AV.6/41/L.19 (1986).

11. Sub-Comm'n Dec. 1987/108, 1987 Report at 53. See also Report of the Working Group on Detention, U.N. Doc. E/CN.4:Sub.2/1987/15.

12. Sub-Comm'n Res. 1987/29, 1987 Report at 41-44. At its 44th session, the Commission on Human Rights approved the appointment of a Special Rapporteur on Economic, Social and Cultural Rights. See Comm'n Res. 1988/22, 1988 Comm'n Report at 71.

13. Sub-Comm'n Res. 1987/17, 1987 Report at 28-29.

14. Sub-Comm'n Res. 1987/24, 1987 Report at 36; adopted by the Commission on Human Rights, Comm'n Res. 1988/45, Comm'n Report at 109.

15. Sub-Comm'n Dec. 1987/101, 1987 Report at 50.

16. Sub-Comm'n Res. 1987/19, 1987 Report at 31.

17. Sub-Comm'n Res. 1987/26, 1987 Report at 38-39.

18. Analysis Concerning the Proposition to Elaborate a Second Optional Protocol to the International Covenant on Civil and Political Rights Aiming at the Abolition of the Death Penalty, Report of the Special Rapporteur, Mr. Marc J. Bossuyt, U.N. Doc. E/CN.4/Sub.2/ $1987 / 20$.

19. The Independence and Impartiality of the Judiciary, Jurors and Assessors and the Independence of Lawyers, Final Report by the Special Rapporteur, Mr. L. M. Singhvi, U.N. Doc. E/CN.4/Sub.2/1985/18 and Add. 1-6; see also Study on the Independence and Impartiality of the Judiciary, Jurors and Assessors and the Independence of Lawyers, U.N. Doc. E/CN.4/Sub.2/1987/17.

20. Study of the Current Dimensions of the Problems of Intolerance and of Discrimination of Grounds of Religion or Belief, Report by the Special Rapporteur, Mrs. Elizabeth Odio Benito, U.N. Doc. E/CN.4/Sub.2/1987/26.

21. Analysis of the Current Trends and Developments Regarding the Right to Leave Any Country 
duced by their authors, these studies were never debated in the plenary and were tabled until another session. Due to the crowded agenda, the inadequate time, the lack of preparation of the experts, and the nervousness about the Sub-Commission elections in 1988, no action was taken regarding these studies, thereby delaying any meaningful debate until either the 40th (1988) or 41 st (1989) sessions.

It will be difficult for future sessions of the Sub-Commission to give reasonable consideration to new items on top of the items which the SubCommission was unable to cover in this session. While there was an extensive discussion at the plenary about developing strategies for streamlining the work of the Sub-Commission, no recommendations or decisions were taken, and this topic also was postponed until the 40th session.

\section{GROSS VIOLATIONS OF HUMAN RIGHTS ANYWHERE IN THE WORLD}

Under agenda Item 6 concerning gross violations of human rights, oral interventions were made regarding the situations in: Bangladesh (Chittagong Hill Tracts), Bulgaria (Turkish Minority), Cyprus, Indonesia (East Timor, West Papua, and the South Moluccas), Iran, Iraq, Kenya, Nicaragua, Occupied Arab Territories, Pakistan (Ahmadi Muslims), Southern Africa, and Turkey. The Sub-Commission adopted resolutions concerning the human rights situation in Chile, ${ }^{22}$ East Timor, ${ }^{23}$ El Salvador, ${ }^{24}$ Iran, ${ }^{25}$ Occupied Arab Territories, ${ }^{26}$ Namibia, ${ }^{27}$ and South Africa. ${ }^{28}$

Draft resolutions on three other country situations, Guatemala, Iraq, and Turkey, were overridden by procedural motions that no decision be taken. The draft resolution on Guatemala noted concern over the persistence of human rights violations, including "disappearances," and mentioned with deteriorating condition of the indigenous population within the country. The resolution was strongly opposed by the Guatemalan government, represented throughout the Sub-Commission session by its Ambassador to Geneva. The Guatemalan Ambassador's strong lobbying campaign focussed on the need for the Sub-Commission to support the recently elected civilian government

Including One's Own, and to Return to One's Own Country, and Some Other Rights or Considerations Arising Therefrom, Final Report by the Special Rapporteur, Mr. C. L. C. Mubanga-Chipoya (First Part), U.N. Doc. E/CN.4/Sub.2/1987/10.

22. Sub-Comm'n Res. 1987/20, 1987 Report at 32-33.

23. Sub-Comm'n Res. 1987/13, 1987 Report at 25.

24. Sub-Comm'n Res. 1987/18, 1987 Report at 29-30.

25. Sub-Comm'n Res. 1987/12, 1987 Report at 24-25.

26. Sub-Comm'n Res. 1987/11, 1987 Report at 21-23.

27. Sub-Comm'n Res. 1987/9, 1987 Report at 18-19.

28. Sub-Comm'n Res. 1987/10, Report at 20-21. 
in its attempt to improve the human rights situation in Guatemala. The discussion noted also that the Central American Peace Agreement presented a real opportunity for a greater respect for human rights that would be jeopardized by the negative terms of the resolution. The motion to take no decision, proposed by Mr. Whitaker (UK), passed by a vote of nine in favor of taking no action, six against, and three abstaining. ${ }^{29}$

The draft resolution on Iraq called upon the Iraqi Government to put an end to human rights violations and proposed the nomination of a Special Rapporteur to investigate the situation. The Arab Lawyers Union, speaking on behalf of lawyers in sixteen Arab countries, noted that Iraq must not be overlooked in the work of the Sub-Commission because the human rights situation in the entire Arab region was worsening, and the situation in Iraq was no exception. The government delegation from Iraq reportedly lobbied Sub-Commission members with great zeal in advance of the vote in order to block passage of the resolution. The decision to take no action was proposed by Mr. Al-Khasawneh (Jordan) who noted that the Sub-Commission had already taken action on Iraq under its confidential communications procedure, ${ }^{30}$ thereby barring a public resolution. ${ }^{31} \mathrm{Mr}$. van Boven (Netherlands) argued that precedents exist for the Sub-Commission to act publicly when a country situation was under the confidential procedure..$^{32}$ Due to an intense lobbying effort on the part of the government, and probably an underlying desire to distinguish between the human rights conditions in Iran and Iraq, the resolution to take no action passed by a vote of $10-6-3 .^{33}$

The decision to take no action on the situation in Turkey proved to be most surprising, largely due to a campaign by non-governmental organizations (NGOs) to discuss the gravity of the situation in Turkey under nearly every agenda item. NGOs such as Amnesty International, the Anti-Slavery

29. Summary Record of the First Part of the 35th Meeting, U.N. Doc. E/CN.4/Sub.2/1987/SR.35 at 6-9.

30. ECOSOC resolution 1503 (XLVIII) empowers the Sub-Commission to examine and bring to the attention of the Commission communications "which appear to reveal a consistent pattern of gross and reliably attested violations of human rights and fundamental freedoms." E.S.C. Res. 1503 (XLVIII), 48 U.N. ESCOR Supp. (No. 1A) at 8, U.N. Doc. E/4832/Add.1 (1970). See also Garber and O'Connor, The 1984 U.N. Sub-Commission on Prevention of Discrimination and Protection of Minorities, 79 AJIL 168 (1985). Petitions, or "communications" are reviewed in closed session by the Working Group on Communications, a pre-sessional working group of the Sub-Commission. The results of the Working Group's decisions are forwarded to the Sub-Commission and then to the Commission, but are not made public until the end of the Commission on Human Rights proceedings, when the Chair announces the names of countries considered under the 1503 procedure.

31. The public admission by Mr. Al-Khasawneh that Iraq was currently being considered in the 1503 process marked a flagrant breach of the secrecy normally accorded the list of countries discussed under the confidential procedure.

32. In the past, at least seven country situations have received both public and private scrutiny. These countries include Afghanistan, Bolivia, Chile, Iran, Kampuchea, Paraguay and Uganda. See H. Tolley, The U.N. Commission on Human Rights, 76 (1987).

33. Summary Record of the 34th Meeting, U.N. Doc. E/CN.4/Sub.2/1987/SR. 34 at 12-13. 
Society, Human Rights Advocates, the International League for the Rights and Liberation of Peoples, and the Minority Rights Group all made strong statements concerning the human rights situation in Turkey, mentioning in particular the systematic use of torture in that country. The government of Turkey was unable to respond to any of the litany of accusations, save by stating that efforts were being made to remedy the human rights situation and denying any institutional practice of torture. The government representative further argued that the draft resolution on Turkey was unduly harsh and that there was no need to establish a Special Rapporteur on Turkey, as proposed in the resolution. A vote to take no action, proposed by $\mathrm{Mr}$. Al Khasawneh, carried by a margin of 9-5-2.34

Two experts, Carey (U.S.A.) and van Boven (Netherlands), suggested that the practice of condemning human rights abuses in country-specific resolutions of the Sub-Commission be revised. Mr. Carey noted that the SubCommission was "on probation" and must strictly adhere to its mandate in considering questions raised under agenda Item 6 . Rather than "making declarations, condemnations and castigations in the style of resolutions passed by the General Assembly or the Economic and Social Council," ${ }^{\prime 35}$ Mr. Carey proposed that the Sub-Commission should refrain from wasting time attacking countries and instead provide credible information on countryspecific human rights situations to the Commission for its consideration. To this end, amendments were proposed to resolutions on Turkey, Iran, East Timor, Palestinian and Arab Territories Occupied by Israel, Guatemala, EI Salvador, and Chile. In general, these amendments proposed to substitute an annex containing reports on the human rights situation prepared by NGOs and IGOs for each country for the substantive operative paragraphs of the resolutions.

The proposal by Mr. Carey that the Sub-Commission simply prepare reports containing information on violations of human rights and fundamental freedoms from all available sources for the use of the Commission, ${ }^{36}$ pursuant to Commission resolution 8 (XXIII) of 16 March 1967, was soundly defeated as an effort to transform the role of the Sub-Commission into that of a "post office" for the Commission. In fact, rather that expedite the work of the Sub-Commission, Mr. Carey's amendments drew strong negative reactions from most of the other experts, except Mr. van Boven, frequently creating long procedural debates. The argument reached its peak when the Sub-Commission agreed by a vote of 6-4-6 that Mr. Carey's amendment to

34. Summary Record of the 36th Meeting, U.N. Doc. E/CN.4/Sub.2/1987/SR. 36 at 3-5.

35. Summary Record of the Second Part of the 33rd Meeting, U.N. Doc. E/CN.4/Sub.2/1987/ SR.33/Add.1 at 3.

36. Mr. Carey referred to U.N. Doc. E/CN.4/Sub.2/1967/286 at 42 , where the record of the 1967 Sub-Commission reflects that the Sub-Commission has in the past attached an annex containing information on violations of human rights and fundamental freedoms from all available sources to the end of country-specific resolutions under Agenda item 6 . 
the draft resolution on the situation in Guatemala did not constitute an amendment, ${ }^{37}$ but a totally new resolution.

Another resolution adopted under the agenda item of gross violations of human rights was a recommendation that countries assist in the speedy recovery of a nation's assets illegally removed by human rights violators, with specific reference to former President Marcos of the Philippines and former President Duvalier of Haiti. ${ }^{38}$

Furthermore, discussions regarding human rights in the U.S.S.R. drifted into an ongoing political debate, with both Mr. Carey (U.S.A.) and Mr. Sofinsky (U.S.S.R.), accusing the other's country of a litany of violations ranging from restrictions on the right to emigrate, and freedom of speech and expression in the U.S.S.R. to the plight of the unemployed and homeless in the United States. ${ }^{39}$ The highly politicized atmosphere was heightened by anti-Semitic remarks made by the expert from the U.S.S.R. in response to accusations by an NGO regarding the rights of Soviet Jews. The Soviet expert was later criticized for his remarks by other members of the SubCommission..$^{40}$

\section{RACIAL DISCRIMINATION}

The Sub-Commission expressed its appreciation to the Special Rapporteur, Mr. Khalifa (Egypt), for his updated report listing all forms of assistance given by banks, transnational corporations and other organizations to the Government of South Africa. ${ }^{41}$ The Sub-Commission invited Mr. Khalifa to continue updating the list and recommended that the services of two UN economists, previously unavailable due to financial constraints, be made available to assist in the preparation of the next report. ${ }^{42}$

A new development was the extension of Mr. Khalifa's mandate to

37. The vote on Mr. Carey's amendment expressed the consensus of the Sub-Commission that an amendment proposing to delete all the substantive portions of a resolution is not an amendment but a completely new resolution. The matter was put to a vote pursuant to ECOSOC rule 63 which defines an amendment as "a proposal that does no more than add to, delete from or revise part of another proposal." Rules of Procedure of the Functional Commissions of the Economic and Social Council, rule 63, U.N. Doc. E/5975/Rev.1.

38. Sub-Comm'n Res. 1987/14, 1987 Report at 26; adopted by the Commission on Human Rights, Comm'n Res. 1988/20, 1988 Comm'n Report at 69.

39. See Summary Record of the 13th Meeting, U.N. Doc. E/CN.4/Sub.2/1987/SR.13; Summary Record of the 16th Meeting, U.N. Doc. E/CN.4/Sub.2/1987/SR.16.

40. Mr.Whitaker (UK), Mr. Joinet (France), and Mr. Carey (USA) warned Mr. Sofinsky against attacking NGOs and making anti-Semitic remarks. See Summary Record of the 15th Meeting, U.N. Doc. E/CN.4/Sub.2/1987/SR.15.

41. Adverse Consequences for the Enjoyment of Human Rights of Political, Military, Economic and Other Forms of Assistance Civen to the Racist and Colonialist Regime of South Africa, Updated Report prepared by the Special Rapporteur, Mr. Ahmad M. Khalifa, U.N. Doc. E/CN.4/Sub.2/1987/8/Rev.1 and Add.1.

42. Sub-Comm'n Res. 1987/7, 1987 Report at 17 ; adopted by the Commission on Human Rights, Comm'n Res. 1988/12, 1988 Comm'n Report at 54. 
include a study of the effects of disinvestment on South Africa and Namibia. ${ }^{43}$ Mr. Khalifa was not present to accept his new task at the time the resolution was adopted..$^{44}$ It appears, however, that he will accept the extension of his mandate to study the effects of disinvestment even though he seemed to be initially reluctant. The Sub-Commission also requested that all countries adopt mandatory comprehensive sanctions against South Africa, that the Government of South Africa lift its state of emergency, and reaffirmed the right of the Namibian people to self-determination.

Further, the Sub-Commission expressed its dismay that the financial situation of the Committee on the Elimination of Racial Discrimination may prevent the Committee from holding its meetings, and recommended that the Secretary-General provide financing on a temporary basis to ensure that the important work of the Committee be allowed to continue. ${ }^{45}$

\section{INDIGENOUS POPULATIONS}

The Working Group on Indigenous Populations held its fifth session from 3 to 7 August, during the week just preceding the 39th session of the SubCommission. All five members of the Sub-Commission, who were elected to serve on the Working Group, attended the Group's fifth session. The Chair/ Rapporteur of the Working Group was again Mrs. Erica-Irene Daes (Greece). The other members of the Working Group were Mrs. Gu Yijie (China), Mr. Alfonso Martinez (Cuba), Mr. Simpson (Ghana), and Mr. Turk (Yugoslavia).

Attendance at Working Group sessions has grown each year of its existence. Twenty-eight governments sent observers. Thirty-three non-governmental organizations in consultative status with ECOSOC sent observers, including ten organizations representing indigenous peoples. Many other indigenous peoples' organizations sent representatives from such places as Argentina, Australia, Belize, Bangladesh, Bolivia, Brazil, Burma, Canada, Chile, Ecuador, Guatemala, India, Indonesia (West Papua and the South Moluccas), Japan, Mexico, Nicaragua, Norway, Philippines, Suriname, United States, and Venezuela. (The 1987 session was marked by a larger number of indigenous representatives from Asia and the Pacific, while fewer Indians from the United States attended.) There were also a number of other organizations and scholars interested in issues relating to indigenous peoples

43. Sub-Comm'n Res. 1987/5, 1987 Report at 16.

44. In its resolution concerning the work of the Sub-Commission, the Commission reprimanded experts for not attending the sessions of the Sub-Commission and called upon all experts to not only attend the sessions but also to take an active role in the deliberative process. See Comm'n Res. 1988/43, 1988 Comm'n report at 103. Mr. Khalifa regularly attends the meeting of the Sub-Commission only for the few days in which his agenda item on South Africa is being discussed, leaving before the Sub-Commission begins its voting procedure.

45. Sub-Comm'n Res. 1987/3, 1987 Report at 14. 
in attendance. In all, approximately 370 persons took part in the session. There were more people in the Working Group session than in most sessions of its parent body, the Sub-Commission.

The Working Group was substantially influenced by the recommendations of a preparatory meeting of indigenous representatives who met in Geneva during the preceding week, from 27 to 31 July 1987, and who also met during most evenings after the close of Working Group sessions. For example, the indigenous representatives drafted a declaration of principles, which was reprinted in Annex V of the Working Group's Report ${ }^{46}$ and which has influenced the Working Group's own Draft Principles. ${ }^{47}$ The Working Group was also influenced by an informal session which it held in September 1986 with non-governmental organizations, since the official session of the Working Group in 1986 had to be cancelled for budgetary reasons.

Although the Working Group has a two-part mandate, that is, (1) to review developments concerning the human rights of indigenous populations, and (2) to develop standards concerning indigenous rights, the Working Group has chosen to concentrate principally on the standard-setting task. At its fourth session in 1985 it proposed seven draft principles protecting (1) the rights under existing international human rights instruments; (2) the right to be free from discrimination; (3) the collective right to exist, to be free from genocide, and the right to life, liberty, and security; (4) the right to religious practices, traditions, ceremonies, and access to religious sites; (5) the right to education, including the right to use their own language and educational institutions; (6) the right to cultural identity and traditions; (7) the right to promote intercultural information and education. Based on the unofficial session of 1986, the Working Group in 1987 proposed three more principles: (8) the right to special State measures for improvement of their social and economic conditions, with their consent, that reflect their own priorities; (9) the right to traditional means of subsistence as well as traditional and other economic activities, without adverse discrimination; and (10) the right to determine, plan and implement all health, housing, and other social and economic programs affecting them.

In addition, the Working Group at the end of its 1987 session proposed several new draft principles: (11) the collective right to maintain and develop ethnic characteristics and identity; (12) the collective right to protection against acts depriving them of ethnic characteristics or identity, including forced assimilation and propaganda against them; (13) the collective right to participate fully in the economic, political, and social life and to have their specific character reflected in the legal system and political institutions of their country; and (15) the duty of the territorial State to grant, within the

46. U.N. Doc. E/CN.4/Sub.2/1987/22, at 30-32.

47. Id. at 23-24. 
resources available, the necessary assistance for the maintenance of their identity and their development. These new standards will be the subject of comment at the 1988 session of the Working Group.

The Working Group has thus far produced a total of fourteen draft principles for a draft declaration on indigenous rights. The Working Group decided to ask its Chair/Rapporteur Mrs. Daes to prepare a complete set of draft principles and preambular paragraphs for a declaration on indigenous rights to be discussed at the Working Group's sixth session in 1988. The Sub-Commission proposed by consensus that the Commission on Human Rights request the Economic and Social Council to authorize such a drafting effort. ${ }^{48}$ This resolution prepares the basis for the Working Group to draft a declaration on indigenous rights which will eventually be issued by the General Assembly.

The Working Group heard much discussion about the right of selfdetermination for indigenous peoples, but has not yet attempted to draft any specific principle on this very difficult issue. ${ }^{49}$ The Working Group also heard conflicting comments about the efforts of the International Labour Organization to revise its Convention No. 107 on Indigenous and Tribal Populations, but made no recommendation on this question. ${ }^{50}$

The preparatory meeting of indigenous representatives recommended to the Working Group that 1992 be declared by the General Assembly the

48. Sub-Comm'n Res. 1987/16, 1987 Report at 26-28. The Commission on Human Rights approved the mandate of Mrs. Daes in Comm'n Res. 1988/49, 1988 Comm'n Report at 113.

49. The Working Group has continued, in general, to use the formulation "indigenous rights" so as to avoid having to declare that the rights belong to "indigenous peoples" who might be entitled to some form of self-determination. The Sub-Commission has begun, however, to use the term "indigenous peoples" rather that "indigenous populations" in its resolutions, thus laying the basis for a potentially significant change in terminology.

'50. In September 1986, a meeting of experts convened to initiate the process of reviewing and revising ILO Convention 107 Concerning the Protection and Integration of Indigenous and Other Tribal and Semi-Tribal Populations in Independent Countries (1957) to better promote the interests of indigenous peoples. The Convention is one of the few international instruments dealing solely with the rights of indigenous peoples.

The published result of the meeting of experts, Partial Revisions of Indigenous and Tribal Populations Conventions, 1957, was distributed at the preparatory meeting of indigenous peoples. Without time to carefully analyze the document, containing articles on land rights, health and welfare, the right to traditional practices and state action, no substantive discussion occurred. (The Sub-Commission is not the appropriate forum for the substantive discussion of an ILO Convention, however, the Working Group on Indigenous Populations is one of the few times that so many representatives of indigenous peoples are in one place.) A collective statement made by the National Aboriginal and Islander Legal Services Secretariat, Indian Law Resource Center, National Indian Youth Council, Inuit Circumpolar Conference, and the International Indian Treaty Council enumerated four initial criticisms of the Convention and the review process established by the ILO. Point four states "the ILO does not offer indigenous peoples reasonable opportunities for effective consultation, participation and negotiation in the revision process, and for monitoring the implementation of the Convention." The revision of ILO Convention 107 has been placed on the agenda for the International Labour Conference in June 1988. 
"International Year of Indigenous Rights." The year 1992 marks the 500th anniversary of the arrival of Columbus in the Western Hemisphere and thus there is a certain irony as well as justification for the selection of that year to emphasize indigenous rights. The Working Group agreed with this recommendation; the Sub-Commission adopted by consensus a resolution asking that the Commission on Human Rights adopt a resolution recommending to the Economic and Social Council that the General Assembly declare 1992 the International Year of Indigenous Rights. At the request of Spain, however, the Commission on Human Rights urged only that an International Year of Indigenous Rights be declared, but removed the idea that 1992 should necessarily be the year selected. ${ }^{51}$

The Sub-Commission also accepted the Working Group's recommendation that Mr. Alfonso Martinez prepare "a study on the treaties concluded between indigenous peoples and States in all parts of the world with regard to the contemporary significance of these treaties for all the parties concerned." 52 The Sub-Commission adopted this resolution by a vote of fifteen in favor with two abstaining (Mr. Carey (U.S.A.) and Mr. Deschenes (Canada)). ${ }^{53}$ The resolution asked the Commission for authorization to appoint Mr. Alfonso Martinez as Special Rapporteur on treaties relating to indigenous peoples. ${ }^{54}$ The Commission on Human Rights did recommend the appointment of Mr. Alfonso Martinez, but limited his mandate to the preparation of an outline on the possible purposes, scope and sources of such a study "giving particular attention to the ongoing development of universally relevant standards and the need to develop innovative, forward-looking approaches to relationships beiween indigenous populations and Governments

51. Comm'n Res. 1988/58, 1988 Comm'n Report at 127.

52. Sub-Comm'n Res. $1987 / 17,1987$ Report at 28-29.

53. A short, albeit highly emotional, debate ensued as Mr. Carey discussed publicly the political and ideological problems he felt were inherent in appointing a Cuban national to study treaties relating to North America. Mr. Carey's offer to join Mr. Alfonso Martinez in conducting such a survey was turned down. (Senator Martinez-Baez [Mexicol also offered to become a co-rapporteur as a compromise solution. This offer was declined as well.) Some members of the Sub-Commission began a public admonition of Mr. Carey for bringing political and national prejudices into the debate, concluding with Mr. Yimer's (Ethiopia) statement that "the discussion on the rationality of an expert marked the saddest moment in his six years of participation in the Sub-Commission's work." U.N. Doc. E/CN.4/Sub.2/ $1987 / S R .35$ at $4-5$.

It seems, however, that Mr. Carey simply tread heavily on the unwritten rules of decorum by publicly airing some of the political considerations which are part and parcel of any deliberative body of the United Nations. The strong reaction to Mr. Carey's statements may also have been fueled by the fear that the Sub-Commission would be perceived as acting in a discriminatory manner, especially given the recent full-scale attack on Cuba by representatives of the USA to the Commission on Human Rights in March 1987 and 1988.

54. The Four Directions Council, a U.S. based NGO representing four North American Indian Tribes and with consultative status with ECOSOC, was the major force behind appointing such a Special Rapporteur. It is thought that the study on the status of Indian treaties will either be conducted by or at least culled from the files of the Four Directions Council. 
taking into account the socio-economic realities of States and the inviolability of their sovereignty and territorial integrity."

In addition, the Sub-Commission by consensus adopted a resolution asking the Commission on Human Rights and then the Economic and Social Council to request the organization in 1988 of "a seminar on the effects of racism and racial discrimination on the social and economic relations between indigenous peoples and States." ${ }^{\prime 56}$ This seminar would be held within the program of advisory services.

The Sub-Commission has heard for several years about the problems which have been encountered by the conflicting claims of the Hopi and Navajo Tribes to territory in Arizona. ${ }^{57}$ This year two members of the Working Group (Mr. Alfonso Martinez and Mrs. Daes) proposed to the Sub-Commission that one or more members of the Sub-Commission attend and observe U.S. congressional hearings both on-site and in Washington, D.C., "to consider further implementation of laws providing for the relocation of Hopi and Navajo families, and to report their observations to the Sub-Commission at its fortieth session." The Sub-Commission adopted this proposal by consensus. ${ }^{58}$ Such an on-site visit would be an innovative initiative for the SubCommission and may set an interesting precedent for future situations. ${ }^{59}$ it must be noted, however, that the visit of a member of the Sub-Commission to U.S. congressional hearings was requested by the Hopi Tribe and it seems that the Hopi elders have agreed to try to raise the funds necessary to undertake such a mission. ${ }^{60}$

Generally, the decisions of the 39th session of the Sub-Commission reflected considerable support for the Working Group on Indigenous Populations and a recognition of the increasing importance of the Working Group as a unique institution in the United Nations human rights structure. The Working Group is the only body which regularly hears directly from groups

55. Comm'n Res. 1988/56, 1988 Comm'n Report at 126.

56. Sub-Comm'n Res. 1987/8 1987 Report at 17-18. The Commission on Human Rights adopted the recommendation of the Sub-Commission to include the study of indigenous populations in future UN activities under the Programme of Action to Combat Racism and Racial Discrimination and to organize a seminar on the relations between indigenous peoples and States. Comm'n Res. 1988/48, 1988 Comm'n Report at 113.

57. Once called the "greatest title problem of the west" Healing v. Jones, 210 F.Supp. 125, 129 (D.C. Ariz. 1962), aff'd 373 U.S. 758 (1962), the conflict arises from a dispute over the use and occupancy of tribal lands in northeastern Arizona. The United States Senate Select Committee on Indian Affairs held brief hearings on the subject of the Hopi-Navajo Relocation Program on 9 December 1987. Additional hearings have not been scheduled to date. Reauthorize Housing Relocation Under the Navajo-Hopi Relocation Program: Hearings on S.1236 Before the Senate Select Committee on Indian Affairs, 100th Cong., 1st Sess. (1987).

58. Sub-Comm'n Dec. 1987/110, 1987 Report at 54.

59. The Sub-Commission has once before authorized an on-site mission to investigate slavery in Mauritania. See Final Follow-up Report on the Mission to Mauritania, prepared by Mr. Marc Bossuyt, U.N. Doc. E/CN.4/Sub.2/1987/27.

60. To date, such a visit has not occurred. 
who are subject to human rights violations and involves those groups in drafting standards to alleviate the violations.

\section{ADMINISTRATION OF JUSTICE AND THE HUMAN RIGHTS OF DETAINEES}

The Working Group on Detention met for a total of five hours in between the morning and afternoon sessions of the Sub-Commission. Two informal meetings which included representatives of nongovernmental organizations were also held in order to facilitate the work of the Working Group. The members of the Working Group, Mr. Alfonso Martinez (Cuba), Mr. Takemoto (Japan), Mr. Dahak (Morocco), Mr. Carey (U.S.A.), and Mr. Turk (Yugoslavia) once again elected Mr. Carey as Chair/Rapporteur. ${ }^{61}$ Also taking part in the discussion were Mr. Joinet (France) and Mr. van Boven (Netherlands) who are not members of the Working Group.

The Working Group on Detention may consider any issue related to Item 9 of the Sub-Commission's agenda, entitled "The Administration of Justice and Human Rights of Detainees." As a sessional Working Group, the members have very limited time to discuss such major issues as the independence of the judiciary and the abolition of the death penalty, the personalization of punishment, the use of force by law enforcement personnel, and the protection of persons subjected to any form of detention and imprisonment. Amidst an ever-growing list of concerns and studies, the Working Group this year made considerable progress on two items in particular: (1) a review of the General Assembly's progress in preparing the Draft Body of Principles for the Protection of All Persons Under Any Form of Detention and Imprisonment; and (2) the development of international standards to prevent extra-legal, arbitrary and summary executions through an adequate investigation, including an autopsy.

The Working Group was asked by Amnesty International and the International Commission of Jurists to review the substantive changes made to the Draft Body of Principles for the Protection of All Persons Under Any Form of Detention and Imprisonment by a working group of the Sixth Committee of the General Assembly. ${ }^{62}$ The Draft Body of Principles was first drafted by the Sub-Commission and recommended to the higher bodies in $1978 .{ }^{63}$ The Sixth Committee of the General Assembly has been reviewing and revising the Draft Body of Principles since 1981.64

61. The Chair/Rapporteur of the Working Group on Detention, Mr. Carey, is the alternate member from the U.S.A.

62. The Sixth Committee of the General Assembly considers and reviews items of a legal nature.

63. See U.N. Doc. E/CN.4/Sub.2/417 (1978). See also U.N. Doc. A334/146 (1979).

64. The most recent version of the Sixth Committee's draft text may be found in U.N. Doc. AVC.6/41/L.19 (1986). 
The overriding concern of both the members of the Working Group and the nongovernmental organizations was that some of the provisions in the current version of the Draft Body of Principles were less protective than existing standards, such as those enumerated in the International Convenant on Civil and Political Rights. The Working Group expressed a clear concern on the following questions: (1) whether under the present text, the principles apply only to persons charged with an offense without protecting the more vulnerable class of persons detained without charge or trial; (2) whether the present reference to a judicial or other authority opens the door to review by an administrative official who may be directly or indirectly linked with an official responsible for an alleged violation of the detainee's rights; and (3) whether safeguards concerning incommunicado detention and habeas corpus proceedings to question legality, necessity, and conditions of detention have in the present text been weakened or fall short of provisions in the International Covenant on Civil and Political Rights, the General Comments of the Human Rights Committee, and the Standard Minimum Rules for the Treatment of Prisoners. ${ }^{65}$

In debating the best approach for raising the level of protection for detainees, it was suggested that the Working Group draft a separate set of principles for those persons detained without charge or trial. This suggestion, however, was not accepted. Instead, the Working Group on Detention recommended that a communication be sent to the Secretary-General expressing the grave concerns of the Sub-Commission regarding the current status of the Draft Body of Principles. The Sub-Commission approved by consensus a resolution requesting the Secretary-General to convey to the working group of the Sixth Committee the concerns raised about the inadequacies of the Draft Body of Principles. ${ }^{66}$

The Working Group on Detention and the Sub-Commission took a bold step in deciding both to critique the work of the Sixth Committee of the General Assembly and to convey its concerns via the Secretary-General to the General Assembly, rather than using the normal channels of communication through the Commission on Human Rights and the Economic and Social Council. Given the timeliness ${ }^{67}$ and the importance of drafting prin-

65. Report on the Working Group on Detention, U.N. Doc. E/CN.4/Sub.2/1987/15 at 6. For a thorough analysis of the Draft Body of Principles, as revised, see The Draft Body of Principles for the Protection of All Persons Under Any Form of Detention or Imprisonment: A Statement of Amnesty International's Concerns, July 1987, prepared by Prof. Douwe Korff, Lecturer at Law, University of Limburg, Maastricht, the Netherlands. Al analyzes each provision of the revised text in light of the original version and existing international standards.

66. Sub-Comm'n Dec. 1987/108, 1987 Report at 52-53.

67. The General Assembly meets from September through December each year. If the SubCommission, which meets each August, chose to convey its message to the General Assembly through the traditional channels, i.e., the Commission on Human Rights and the Economic and Social Council, the communication would not reach the General Assembly 
ciples for the adequate protection of detainees, a more thorough discussion by the Sixth Committee on the scope of the principles and the definitions used was sparked by the criticisms received from the Sub-Commission.

The Working Group on Detention for the first time considered the issue of developing international standards for the investigation into suspicious deaths and deaths in custody, including an autopsy. The International Commission of Jurists submitted a draft set of standards prepared by the Minnesota Lawyers International Human Rights Committee which outlined the need for death investigations and offered a preliminary set of requirements necessary to facilitate a proper investigation. ${ }^{68}$ Representatives of the National Aboriginal and Islander Legal Services Secretariat noted that the need for death investigation standards was particularly appropriate to the situation in Australia, following the inauguration of an Australian Royal Commission to investigate the recent upsurge of aboriginal deaths in custody. ${ }^{69}$

The Working Group noted that the development of international death investigation standards deserved much more attention and consideration than was available. The Working Group noted also the rise of arbitrary killings throughout the world, the recent recommendation of the Special Rapporteur on Summary and Arbitrary Executions for the establishment of a set of investigation standards, and the efforts made by the UN Committee on Crime Prevention and Control to draft standards on this subject. ${ }^{70}$ The Working Group informally agreed to give priority to this issue at its next meeting in 1988.71

for at least a year. By sending a communication via the Secretary-General, the SubCommission was assured the message would reach the General Assembly in time for its Fall 1987 meetings. Since the Sixth Committee continues its annual review of the Draft Body of Principles, it was imperative that all concerns regarding the revision process be communicated promptly.

There was some discussion at the Commission concerning rescheduling the annual calendar of UN human rights meetings so that no more than a year would pass before a resolution or decision could reach the General Assembly after being adopted by the SubCommission, the Commission and ECOSOC.

68. Report of the Working Group on Detention, U.N. Doc. E/CN.4/Sub.2/1987/15, Annex VI at 28-32. See also id. Annex III at 18-20, an explanatory paper concerning the elaboration of norms guaranteeing an impartial investigation into arbitrary execution or suspicious violent deaths, in particular during detention, prepared by Mr. Joinet (France).

69. See Annex VI (C) of the Report of the Working Group on Detention for a reproduction of the statement made by the National Aboriginal and Islander Legal Service Secretariat.

70. The 42 nd session of the General Assembly made a particular reference in support of developing international death investigation standards. The General Assembly resolution on summary or arbitrary execution "endorses the recommendation of the Special Rapporteur on the need to develop international standards designed to ensure effective legislation and other domestic measures so that proper investigations are conducted by appropriate authorities into all cases of suspicious death, including provisions for adequate autopsy." G.A. Res. 42/141, adopted 7 December 1987 without a vote.

71. The most recent report of the Special Rapporteur on summary or arbitrary executions details at length both the need to establish international investigation standards and the necessity for continued collaboration between the Centre for Human Rights and the Crime Prevention 
The Chair/Rapporteur of the Working Group on Detention, Mr. John Carey (U.S.A.), was asked to obtain all available documentation on a draft set of principles and prepare and disseminate an analysis and conclusions to both members and interested NGOs in time for the 1988 meeting of the Working Group. ${ }^{22}$ This decision was adopted by consensus as a resolution of the Sub-Commission. ${ }^{73}$

In addition, the Working Group requested that the Sub-Commission recommend to the Commission on Human Rights and the Economic and Social Council a declaration that arbitrary or abusive use of force by law enforcement personnel in any country should be punished as a criminal offense. ${ }^{74}$ The Working Group also requested that the Sub-Commission request the Secretary-General to gather all pertinent information from governments and intergovernmental and nongovernmental organizations concerning the individualization of prosecution and penalties, and repercussion of violations of human rights on families. The request noted further that a member of the Working Group should prepare a paper outlining steps to be taken by the Working Group on the individualization of penalties, including the advisability of appointing a Special Rapporteur on the subject. Finally, the Working Group agreed to examine at its next meeting the feasibility of preparing a booklet on the restraints on the use of force by law-enforcement personnel. The Sub-Commission adopted these decisions of the Working Group by Consensus. ${ }^{75}$

Unfortunately, two important items concerning the administration of justice and the human rights of detainees were not adequately considered by the Sub-Commission. The discussion of Mr. Singhvi's (former Sub-Commission member from India) voluminous report on the independence of the judiciary, as well as the report by Mr. Bossuyt (former member from Belgium) on the abolition of the death penalty, were given only cursory attention due both to a lack of time and unavailability of the reports in Russian. Hence, any discussion on a draft declaration on the independence of the judiciary or a second optional protocol on the abolition of the death penalty must wait yet another year. ${ }^{76}$ Even a procedural resolution requesting that $\mathrm{Mr}$.

and Criminal Justice Branch of the UN Centre for Social Development and Humanitarian Affairs in developing such standards. Summary or Arbitrary Executions, Report by the Special Rapporteur, Mr. S. Amos Wako, pursuant to Economic and Social Council resolution 1987/60, U.N. Doc. E/CN.4/1988/22 at 30-32.

Unfortunately, the next meeting of the Committee on Crime Prevention and Control at which such draft standards will be discussed, is scheduled for August 1988 in Vienna, thus in direct conflict with the 40th session of the Sub Commission.

72. Report of the Working Group on Detention, U.N. Doc. E/CN.4/Sub.2/1987/15 at 8.

73. Sub-Comm'n Dec. 1987/108, 1987 Report at 52-53.

74. Id. The Commission, however, did not directly address recommendation in its resolutions and decisions.

75. $l d$.

76. The Commission, however, has reiterated its request that the Sub-Commission give priority 
Bossuyt's's report be transmitted to the Commission for its information was tabled owing to the absence of some of its sponsors during the vote. ${ }^{77}$

While the Working Group on Detention continues its thorough examination of issues relating to the administration of justice and the human rights of detainees, many of its products seem to be stymied at the Sub-Commission level. The inability of the Sub-Commission, for political or other reasons, to go forward with such significant studies as the independence of the judiciary and the abolition of the death penalty, as well as a recent report on states of emergency, impedes much potential progress in the field.

\section{OTHER}

The Working Group on Slavery and Slave-like Practices ${ }^{78}$ met during the week prior to the Sub-Commission and considered issues concerning the problems of prostitution, the exploitation of children, bonded labor, the trafficking of human organs, a report on slavery in Mauritania, ${ }^{79}$ and the proposal to change the name of the Working Group reflect more current themes related to slavery ${ }^{80}$ The Working Group was at a disadvantage due to the absence of three of its members, including the sudden death of its Chair, Mr. Justice Chowdhury (Bangladesh), as well as a low turnout of NGOs during the meetings.

Over the past few years, substantial debate has centered upon whether or not the Working Group on Slavery should continue to exist. ${ }^{81}$ Critics insist that the mandate of the Working Group is overly broad, allowing members to discuss and act upon nearly any and all human rights questions, thereby increasing the chance of duplicating the work of the Sub-Commission. Sec-

to these issues. Comm'n Res. 1988/33, U.N. Doc. E/CN.4/1988/L.11/Add.5 at 7; Comm'n Res. 1988/40, U.N. Doc. E/CN.4/1988/L.11/Add.5 at 19-21; Comm'n Res. 1988/104, U.N. Doc. E/CN.4/1988/L.11/Add.3 at 4.

77. Messrs. Joinet (France), Martinez-Baez (Mexico), and Whitaker (U.K.), all co-sponsors of the resolution, were not present to vote. Subsequently, a motion made by Mr. Sofinsky (U.S.S.R.) to take no action on the resolution to transmit the analysis and comments on a Second Optional Protocol to the Commission on Human Rights passed by a margin of 1 vote. The official tally was four votes in favor, three opposed, with six abstentions. Although the reason given for the failure to consider even a procedural resolution on the death penalty was the unavailability of the report in all languages (particularly Russian), it must be noted that it is very difficult to pass any resolution concerning abolition of the death penalty. (CF. U.N. Doc. E/CN.4/Sub.2/1987/SR.35 at 2, where the expert from the U.S.S.R. agreed to proceed with voting on a resolution concerning indigenous populations even though it was not available in Russian).

78. Report of the Working Group on Slavery, U.N. Doc. E/CN.4/Sub.2/1987/25.

79. Final Follow-up Report on the Mission to Mauritania, prepared by Mr. Marc Bossuyt, U.N. Doc. E/CN.4/Sub.2/1987/27.

80. In its Resolution 1988/42, the Commission on Human Rights endorsed the proposal to change the name of the Working Group to the "Working Group on Contemporary Forms of Slavery." Comm'n Res. 1988/42, 1988 Comm'n Report at 102.

81. For an in-depth study of the role and history of the Working Group on Slavery, see Zoglin, United Nations Action Against Slavery: A Critical Evaluation, 8 Hum. Rts. Q. 306 (1986). 
ondly, critics argue that the Working Group is dominated by a small constituency of NGOs who are in essence responsible for setting the agenda and the course of the work on slavery and slave-like practices. With only a limited amount of time and resources available to the Sub-Commission and its working groups, some experts have questioned the necessity of using five precious days prior to the Sub-Commission for issues relating to only a small constituency. Informal suggestions for making the Working Group on Slavery a sessional working group, or, to create a biennial working group, have yet to bear fruit.

The supporters of the Working Group on Slavery, most notably the AntiSlavery Society, have at present been able to justify the existence of the working group. Noting that the problem of slavery and slave-like practices is one of the oldest and longest-lasting forms of human rights abuse, it is much too important to dismiss. The Anti-Slavery Society maintains that issues such as prostitution, the exploitation of children and the trafficking of human organs must continue to be closely monitored and addressed by the United Nations, and the Working Group on Slavery is the best forum to initiate studies and plans of action. To date, the Working Group on Slavery will continue to hold its pre-sessional meetings. Any substantive discussion concerning the future role and purpose of the Sub-Commission, however, will most likely include a debate on the future of the Working Group on Slavery. ${ }^{82}$

The Working Group on the Rights of the Mentally-Ill met for four hours during the Sub-Commission session and continued its work in developing draft standards for the protection of the mentally ill. ${ }^{83}$ The Working Group and the participating NGOs expressed their frustration at the slow pace of the progress being made and voiced their concerns that more attention be given by the Sub-Commission to this Working Group. ${ }^{84}$

The Sub-Commission heard reports on the right to adequate food under the new international economic order ${ }^{85}$ and the question of human rights

82. The Commission on Human Rights adopted a resolution in support of the Working Group on Slavery at its 1988 session. In fact, the Commission offered suggestions concerning the future work of the Working Group. These suggestions include requesting that the Working Group draw up a plan for its future work with a particular focus on child prostitution and child pornography, and a recommendation that a Special Rapporteur be appointed to review the implementation of a program of action aimed at the prevention and suppression of slavery-like practices. Comm'n Res. 1988/42, 1988 Comm'n Report at 102. It seems that the Commission, while being supportive of the Working Group, suffers from the same struggle as the Sub-Commission to better define the mandate of the Working Group on Slavery.

83. Report of the Sessional Working Group on the Question of Persons Detained on the Grounds of Mental III-Health or Suffering from Mental Disorder, U.N. Doc. E/CN.4/Sub.2/1987/32.

84. The Commission expressed its frustration and dissatisfaction that the Working Group has been unable to make any substantial progress on elaborating draft standards for the protection of the mentally ill. The Commission further requested the Sub-Commission to "attach much greater emphasis to the Working Group and its drafting assignments." Comm'n Res. 1988/62, 1988 Comm'n Report at 133.

85. Report on the Right to Adequate Food as a Human Right, prepared by the Special Rapporteur, Mr. Asbjorn Eide, U.N. Doc. E/CN.4/Sub.2/1987/23. 
under states of emergency, ${ }^{86}$ but postponed action on these reports. Other resolutions of note included a statement of concern for the detention of fiftyone UN staff members in various countries of the world, ${ }^{87}$ an offer of assistance to the Secretary-General in developing guidelines for access to the war crimes files held by the former UN War Crimes Commission, ${ }^{88}$ and a routine call for all states to ratify the international conventions relating to human rights. ${ }^{89}$

\section{CONCLUSIONS}

The 39th session of the Sub-Commission on the Prevention of Discrimination and Protection of Minorities was burdened with work accumulated over two years and was thus unable to handle the voluminous amount of material before it. The Sub-Commission failed to give adequate consideration to several substantial reports and studies aimed at furthering its work in standard-setting and information-gathering on human rights problems. Nevertheless, the Sub-Commission proposed a few new studies. The best products of the Sub-Commission came from its Working Groups on Indigenous Populations and on Detention. More thought must be given to the review of the work of the Sub-Commission so that it may continue to provide meaningful assistance to the Commission on Human Rights. ${ }^{90}$

86. First Annual Report and list of States which, since 1 January 1985, have proclaimed, extended or terminated a state of emergency, presented by Mr. Leandro Despouy, Special Rapporteur, U.N. Doc. E/CN.4/Sub.2/1987/19.

87. Sub-Comm'n Res. 1987/21, 1987 Report at 33-34. The resolution makes specific mention of UN Staff member Livio Botha, a Romanian national who was detained by his home government for two years and prevented from returning to his family in Geneva. Mr. Botha was released by the Romanian Government on 12 February 1988. N.Y. Times, Feb. 13, $1988, \S 1$, at 4 , col. 1. It is possible that the Romanian Government released Mr. Botha just prior to the 1988 session of the Commission on Human Rights to avoid being mentioned in a resolution of the Commission.

88. Sub-Comm'n Res. 1987/2, 1987 Report at 13-14. On 31 October 1987, the New York Times reported that the "Allied War Crimes Commission" announced on October 30 the approval of a plan to open the files of the War Crimes Commission to scholars, writers and diplomats. N.Y. Times, Oct. 31, 1987, $\$ 1$, at 4, col. 1.

89. Sub-Comm'n Res. 1987/1, 1987 Report at 13. Rather than accept the resolution of the Sub-Commission, the Commission on Human Rights at its 1988 session adopted its own resolution in which the language encouraging all States to ratify international human rights instruments is substantially weaker than that adopted by the Sub-Commission. Comm'n Res. 1988/27, 1988 Comm'n Report at 80. See generally Weissbrodt, A New United Nations Mechanism for Encouraging the Ratification of Treaties, 4 Hum. Rts. Q. 333 (1982).

90. See Comm'n Res. 1988/43, 1988 Comm'n Report at 102. In its resolution concerning the work of the Sub-Commission, the Commission recognized the need to streamline the work of the Sub-Commission. To this end, the Commission offered a little guidance. The suggestions adopted included: an admonition not to undertake new studies when old studies are still in progress; restricting requests to the Secretary-General to asking Governments, 1GOs, and specialized agencies for their views and comments only on those studies which have 
Although a number of important resolutions regarding detention and gross violations of human rights were adopted, the Sub-Commission displayed an unwillingness to tackle sticky human rights issues which may have political overtones, such as the death penalty, religious intolerance, and the right to leave and return. The reluctance of the Sub-Commission to deal with those issues may have been due to the forthcoming election in which the experts may or may not be renominated by their governments and then selected by the Commission in March 1988.91 Perhaps the 40th session of the Sub-Commission in summer 1988 will be more effective in protecting and promoting human rights. The fear exists, however, that a completely new panel of experts ${ }^{92}$ appointed to the 40 th session will need time to acclimate themselves to the Sub-Commission, and may have different interests and personal agendas, leaving the prior work of the Sub-Commission dormant.

At this juncture, a serious question among experts on the United Nations human rights procedures arises as to whether the Sub-Commission should exist at all. Given the severe budgetary limitation placed on the United Nations as a whole, can the institution continue to support a body which is increasingly unable to handle its workload, is mired in procedural battles, and to some extent duplicates the work of its parent body, the Commission on Human Rights?

While the Commission pays little attention to the work of the SubCommission during its March meetings, there are a number of justifications for the continued existence of the Sub-Commission. The Sub-Commission is one of the few deliberative organs concerned with human rights whose members are elected in their individual capacity. While regional politics do affect some of the debates and decisions of the Sub-Commission, the less politicized atmosphere makes the Sub-Commission more open to innovative projects and ideas. The successes of the Working Groups on Indigenous Populations and Detention are examples of the type of work which the SubCommission is able to accomplish.

received prior explicit approval from the Commission; giving priority to work in the field of standard-setting in accordance with decisions of the Commission and ECOSOC; avoiding long procedural debates, focusing substantive attention on work which is not being pursued by other United Nations bodies, and making an extra effort to ensure the translation of reports into all languages.

91. Only one incumbent member of the Sub-Commission, Mr. Mubanga-Chipoya from Zambia, was defeated in his quest for reelection.

92. At its 1988 session, the Commission on Human Rights elected fifteen new experts to the Sub-Commission. Six new countries-Algeria, Costa Rica, Nigeria, Norway, Philippines, and Togo-are now represented at the Sub-Commission. There are now six women representatives, as compared to only one (Mrs. Daes) in the 1985 and 1987 sessions. New representatives from China, Colombia, Japan, Mexico, Morocco, Romania, U.K., U.S.A., and U.S.S.R. were nominated by their governments and elected by the Commission. No longer represented at the Sub-Commission are Canada, Ecuador, Ghana, and Zambia. See 1988 Comm'n Report at 274-76. 
Secondly, the Sub-Commission is by far the most accessible human rights body to NGOs. Sessions of the Sub-Commission are attended by hundreds of NGOs who are given the opportunity not only to provide information on human rights violations throughout the world, but also to confront observer governments with various allegations. The opportunity for dialogue between NGOs and observer governments must not be downplayed. Many times, the Sub-Commission sessions provide the only forum throughout the year for these two groups to talk and negotiate. Governments that are reluctant to meet or deal with their critics during the rest of the year feel compelled to defend themselves, both privately and publicly at the meetings of the Sub-Commission. The opportunity for dialogue between these two camps is one of the most positive results of every session of the Sub-Commission.

Furthermore, the pre-sessional meetings of the Working Group on Indigenous Populations are the only public international forum for representatives of indigenous peoples not only to be heard, but to participate in drafting international standards for the protection of their rights. Unlike all other meetings of UN bodies, representatives of indigenous peoples may actively participate in the work of the Working Group without first obtaining consultative status under ECOSOC. The ever-increasing numbers of indigenous representatives who travel to Geneva for the Working Group indicate the significance of this forum to the protection of indigenous rights.

One must also consider the level of overall substantive progress which comes out of the Sub-Commission. Can the Sub-Commission learn to streamline its agenda? Is the work of the Sub-Commission innovative enough to justify its existence, or can the Commission effectively take on many of the responsibilities? Does the annual calendar of the United Nations impede the progress of human rights by creating such a time lag between the meetings of the Sub-Commission, the Commission and ECOSOC that important items are not acted upon swiftly, and others are simply swept under the carpet?

These questions, among others, must be addressed so as to make the human rights procedures in the United Nations more effective. The SubCommission can no longer avoid discussions on its role and purpose. 